\title{
Threats posed by serious and organised crime for the safety and security of tourism in Poland
}

\author{
Kamil Martyniak $^{1}$, \\ ${ }^{1}$ Andrzej Frycz Modrzewski University \\ Grudzińskiego 1, 30-705 Kraków - Poland
}

\begin{abstract}
The growing impact and relevance of safety and security in tourism can be discerned in the increasingly more substantial foreign and Polish academic literature on the subject. Based on the available publications and enhanced by the author's individual reflections and tourist experiences, the paper attempts to outline a number of issues selected arbitrarily by the author. The goal of this paper is to attempt to define the various threats posed for the safety and security of tourism in Poland, and to look at the salient problems and dilemmas that may, in the nearest future, become the object of further research and enquiries.

Being absorbed by the trip implies that tourists frequently fail to pay enough attention to the dangers that await them. Situations of this sort are, indeed, numerous: some are caused by the people themselves, and the origins of others need to be traced in nature. The role of tourism organisers and travel agencies, as well as tourists themselves, is to strive to make sure that trips made to get some sunshine, bathe in warm water sofexotic seas, and expeditions to the mountains do not turn into a nightmare (Mansfeld 2006). Each type of tourism has its unique specificity that goes with smaller or bigger chances of fortuitous events. It is not just the specific nature of the above types of tourism that can trigger a variety of fortuitous events, but also at the individual stages of consumption of a tourism product (Sanetra\&SanetraPólgrabi 2018) situations can occur that are caused by factors related to tourist transport, and staying at a given rest spot. Admittedly, the essence of tourism rests on people's travelling to destinations that pride themselves on outstanding tourist qualities, and that are located beyond the place where tourists reside on a permanent basis. This form of travelling constitutes the basic element of the consumption of tourism. This paper is the fruit of critical literature-based research, and desk research conducted on the subject matter at hand.
\end{abstract}

Index Terms - serious and organized crime threats, tourism, security, tourist destinations

\section{INTRODUCTION}

Admittedly, the major area in which the state has an impact on tourism demand ought to be the shaping of tourism activity of its inhabitants. Exerting an influence on inbound tourism bears the hallmarks of a demand-driven policy, but it is only related to the indirect aspects, as it focuses on supporting the supply system, and, primarily, on the expansion of tourism and

ASEJ - Scientific Journal of Bielsko-Biala School of

Finance and Law

Volume 24, No 2 (2020), 5 pages

DOI: $10.5604 / 01.3001 .0014 .3292$

Received: 29.05.2020; Accepted: 24.06.2020 para-tourism infrastructure, creating offers, and promotion. These activities are aimed at creating a demand-driven effect amidst tourists who come to visit a given area, and who may be motivated by a policy that supports demand from the country of origin. A case in point is the growing offer of health tourism in West-Pomeranian health resorts, primarily in Kołobrzeg, for tourists/visitors/patients from the eastern regions of Germany who take advantage of a variety of offers funded by the regional branches of the country's National Health Service. As part of its social policy, the state ought to create the right conditions that allow people to benefit from the advantages of tourism on a mass scale, and, hence, make it easier to take advantage of selected offers in the tourism market from the following two perspectives (Wodejko 1998, p. 170):

- subjective: for example, aimed at children, and/or teenagers,

- objective: for example, aimed at social tourism, health tourism, (including health resort tourism), family tourism, educational tourism, and culture tourism.

The entity responsible for tourism policy in Poland is the minister competent for tourism-related matters, i.e. the Minister of Sport and Tourism. Practically, none of the tasks performed by this body are related to demand-driven issues beyond:

- the support given to activities undertaken for the recreation of children and teenagers, which belongs to the competence of the minister competent for physical education and sports; clearly, in light of the current system of government administration, these competences refer to one government department;

- consumer rights protection, which is the general instrument that regulates relations in the market of tourist services. Units of local and regional authorities of all tiers are legally obligated to carry out tasks for the benefit of children's and teenagers' tourism (Kowalik 2000, p. 12).

This task is carried out at the level of educational institutions by the local authorities being the founding bodies of primary schools, middle schools and secondary schools, and it goes down to the fact that these institutions organise and, when the need arises, apply for co-funding to the relevant local

Regular research paper: Published 06.2020

Corresponding author's e-mail: kamil.m.martyniak@gmail.com Copyright (C) 2018 This is an open access article distributed under the Creative Commons Attribution CC-BY-NC 4.0 License. 
authorities that run nature schools. One of the social policy activities carried out at the level of businesses and institutions are funding incentives as part of a variety of social benefit funding schemes, and they are related to organising holidays at company holiday facilities for employees and their families, as well as organising holidays for children and teenagers of the staff, and co-financing recreational activities commonly referred to as self-arranged countryside holidays. Apparently, the latter form is the least effective, as the funds that employees get on this account are not always allocated on tourism, or tourism-related activities.

The major area of state policy as regards tourism demand is consumer protection. Indeed, the key instrument of tourism policy that as an impact on the consumers of tourist services is the Polish Tourism Services Act. Its overriding goal is to protect consumer interests (Horodecka 2008, p. 18). Chapter 3 of the Act refers to the issues related to the provisions of agreements made by clients and organisers of tourist services as regards: accurate specification of the object of performance, setting and altering the price(s), liability for failure to perform the agreement and the consequences of rescission. It is, however, an area that is not strictly connected to the stimulation of tourism demand, just as the activity of Poland's Office of Competition and Consumer Protection, whose major role is to protect consumers' interests. If tourist enterprises/travel agencies use forbidden practices for their clients, such as e.g. inadmissible standard agreements, or are in breach of the duty to provide accurate, truthful and complete information, consumers may file a report concerning the violation of collective consumer interests.

Undoubtedly, both tourism and crime are phenomena that can be commonly encountered also in Poland. The former has, in principle, resonates positively, as it is generally regarded as a positive issue. It is often a major factor that stimulates economic growth of countries, regions, or towns/cities. It has a positive impact on the material conditions of societies, and - as has frequently been noted - contributes to the preservation of nature and protection of monuments. The turn of the 1960s and 1970s witnessed the first major critical publications related to tourism. They looked at the negative effects of the growth of tourism in Poland, mainly through the prism of foreign inbound tourism. Despite a number of easily discernible negative consequences of the growth of tourism, there are still only a few publications that examine this issue. Undoubtedly, these academic endeavours are dominated by papers and monographs originating from the English-speaking countries. In Poland, the issue of the broadly defined negative effects of the growth of tourism has been extensively developed by Przecławski (1983). Łaciak and Bartoszewicz (1989), in turn, look at the impact of tourism on the natural, social and cultural environment in tourist destinations. Yet, there is a clear lack of academic analyses that would bridge this major gap, especially on the level of Polish cities.

\section{LITERATURE OVERVIEW}

Nowadays, in the age of post-modernism, tourists are on the one hand more and more experienced and well-travelled ("they have been everywhere and have seen everything"), bored with the traditional offers; on the other hand, they expect more and more stimuli, and unforgettable experiences. As a result, they can no longer be satisfied with just an "ordinary" form of relaxation, or sightseeing, and they wish to take part in something extraordinary, be surprised at all times, and experience a one-of-a-kind holiday adventure (Idziak 2009).

One of the consequences of this incessant pursuit of novelty, otherness and surprise is the need to experience more and more new and stronger stimuli, experience more extreme emotional states, be part of a variety of events that get them an adrenaline rush and have never been come about before. Given the growing demand for unique holiday experiences, the tourist industry is offering more and more surprising, challenging, extravagant and shocking products that are often bloodcurdling too (Stasiak 2015). The desire to experience a "male adventure", have a brush with real danger or death, experience absolutely extreme emotions - like fear, ecstasy, or euphoria can be regarded as the primary, or at least one of the main, driving forces and objectives of travelling for amateurs of strong sensations. As regards the commercial market offer, the need to experience extreme sensations should be regarded as the core of such a specific tourist product. Maybe in the future, it will play an increasingly bigger role, pushing the traditional cognitive, relaxation, health-related or spiritual "needs" of tourists to the side, and maybe it will remain the fundamental part of the real nature of the product itself exclusively in the niche extreme segment of the tourist industry. The real product in this model will be all the goods and services that allow people to experience an outstanding and energizing "adventure", e.g. a survival camp in pre-arranged oppressive conditions. The extended product, in turn, would be made up of all the additional elements that would enhance the participants' experiences and would make the product more attractive in their eyes, e. g, such documented adventures that will make sure its participants get enough admiration and/or respect with their friends or relatives. The fact that these are not just purely theoretical considerations is further substantiated by a closer look at the current tourism market, where one can more and more often notice products that pose a real bigger or smaller threat on tourists' safety and security. The source of danger can be both the form of travel, the type of activity taken at the destination, and the very nature of the visited area. High-risk travel encompasses e.g. extreme tourism, slum tourism, and disaster tourism (Stasiak 2015).

Amidst the major problems of modern tourism and the already listed dysfunctions which need solving in a not too distant perspective also in Poland, one should list, among others, social cohabitation through the lens of recreation. "It is obvious that the key condition for the attainment of a durable and sustainable growth is the fundamental change of the structure of human needs alongside an authentic change of the hierarchy of values" (Piontek et al. 1997). Just like in the natural course of evolution genetic diversity in the biological 
dimension is vital to guarantee survival and to safeguard a certain level of wellbeing and balance, so does diversity, seen as a value in its own right, manifest itself in the social dimension through the multitude of lifestyles, customs, habits, and tolerance for otherness. Tourism can indeed enrich people, becoming an autotelic value in itself. It may happen, however, that is the source of alienation, as it dynamisms the sense of frustration of individuals and social groups. There are situations where a human being, or even entire societies, are exposed to a loss of subjectivity, autonomy, and possessions. At that time, it is possible to see that the disorder of the human world is merely a transient state and one that be reversed.

The principle of sustainable tourism sets the overall perspective and the tasks for the next generations, attempting to meet the expectations of the dominating and natural tendency accepted by the majority of people with a commonsensical attitude, whereby one needs to care about one's place on planet Earth, especially in light of the fact that it is our unique place as long as we are alive. Such care includes the natural and cultural heritage, and, in principle, is based on an ethical principle that can be tersely worded in the following way: "We should not live at the cost of others, or the future generations". What matters, indeed, is a development of culture that would pursue a universal principle of equality of opportunity, and social justice. The concept of sustainable tourism is also enhanced by the "principle of responsibility", which points to the positioning of the human being in the world indeed as a "responsible position. "The conviction put forward by H. Jonas (1996: 47) which admits that "our responsibility reaches beyond our life" refers to the generations that will succeed us and touches upon the core of the very idea of sustainable development. Arguably, we are currently witnessing a gradual widening of the area of responsibility. There are growing requirements that take into account co-responsibility. Such subsystems as science, the economy, or politics are fully acknowledged in terms of their right to operate not only on the basis of internal criteria that specify their rationality, but by moral criteria related, among others, to the consequences of their functioning and application of their results. Given the present situation, epitomised by a significant level of uncertainty, insecurity and danger, being just sensitive or having a sense of good to minimize the negative consequences of several actions and decisions is definitely not enough. What is really needed is a certain knowledge that, along with a professional course of actions, assumes an ethical meaning in line with the principles of the legal understanding of an individual's being within society.

\section{RESEARCH FINDINGS}

Admittedly, serious and organised crime concerns tourists in two ways: as victims of criminal offences committed against them, which is obvious and part of common conscience; and as perpetrators and accomplices, which is more rare. During their holidays, tourists want to forget about their everyday problems, relieve stress, and detach from reality. Consequently, while away from home, many people experience a significantly lower level of self-control, and even a conscious rejection of the rules and principles of conduct they follow every day. Taking advantage of the feeling of anonymity, and hence impunity, at their holiday spot, as well as a "sense of freedom" conceived of in their own unique manner, they behave in a way they would never behave in their place of permanent residence: e.g. abuse of alcohol, intake of drugs and psychoactive substances, indecent behaviour, casual sexual intercourses, prostitution, property damage, getting into fights, taking part in illegal gambling activities, or smuggling goods across borders. Breaking the law can be inadvertent and unintentional, and can result from having little or no knowledge of the local laws, but it can also be conscious and arranged in advance to gain expected profits (Stasiak 2015). However, tourists become a lot more often victims of criminal offences: above all pickpocketing (stolen money, cards, or documents);stolen electronic equipment (mobile phones, digital devices, videocameras, etc.); stolen luggage at airports, during transfers, or at accommodation facilities; fraud (e.g. at currency exchange points, taxis, at street markets); cases of assault and/or battery; and recently also cybercrime, including cases of stolen identity, access codes to electronic banking services, and/or unwanted bank transfers. These are generally instances of so-called distraction crime (Lisowska 2017), which are the consequence of a specific sense of being lost and experiencing some sort of mental confusion or even disorientation that can be discerned in tourists who are in a completely new place that is strange and unknown to them. Additional risk factors here are: reduced alertness and caution, which is the effect of a holiday mood, a sense of excitement by the journey, being absorbed by sightseeing, use of alcohol, and carefree fun, as well aslittle or no knowledge of the local language, customs, no-go areas, etc. As a rule, tourists stand out from the locals with the way they look, what they wear, how they behave, which implies an almost immediate attention attracted to them by the local criminals. Since they usually have large amounts of money or valuables on them, they become a "lucrative" and relatively easy theft targets. Based on the review of foreign literature on the subject, Lisowska (2017) has reached the conclusion that for a majority of tourists, the fear of "conventional" crime is not a good reason to abandon their plan to travel to a particular place. Admittedly, the level of fear not always reflects real danger: it is frequently conditioned byother social and demographic factors, such as age, physical weakness, place of residence, professional status, travel experience, or the level of trust in the police, not to mention the general image shaped by the media. Having said this, there is absolutely no doubt about the fact that the way in which tourists perceive safety and security is a major element that moulds the general image of a given tourist destination, which, in turn, has a fundamental influence on both the growth of tourism and the entire economy of a particular region. Tourism is without doubt the "driving force" of the economy of a particular region, town, city, or entire country. Tourism attractiveness is generally defined as a particular quality of areas, localities, or facilities that is above all made up of a given scale of tourism values, a specific degree of accessibility, and the level of development of tourist facilities (Rogalewski 1972, p. 35). One must not forget, however, that 
feeling safe, stable and secure is a major decisive factor as regards the choice of a particular tourist destination, which explains why multi-faceted research of these issues is of key importance. Yet, one of the key difficulties here is to determine the actual number of criminal offences committed, which is related to the fact that in actuality, a majority of crimes committed against tourists is never reported. The factors underlying this type of behaviour are as follows (Tarlow 2011):

- directly following the incident, most tourists are not aware of the fact that they have become victims of a crime, which regards primarily pickpocketing; indeed, during holiday trips the level of travellers' alertness is lower;

- $\quad$ sometimes it happens that the victim of a crime does not know what to do at the moment of attack; s/he usually has no idea where the incident took place, or where to report it; therefore, it is easier to forget about the whole thing, especially when one does not have a fluent command of the local language;

- the victims of a crime are often convinced that they will not get their stolen things back; hence, reporting such incidents anywhere seems completely useless to them.

Some tourists become victims of crimes in which they are involved as accomplices or provocateurs. In such situations, we are dealing with a desire not to reveal such incidents, which results in there being no report and no information in police statistics. As a result, looking into crime among tourists may turn out to be unreliable. Crime in tourism can be defined in a variety of ways. Some authors admit that a specific classification ought to be introduced, independent of those used by the police, of criminal offences and acts of violence encountered in tourist destinations (Pizam 1999), which, however, could turn out to cause further trouble. Looked at in a different and simpler way, this issue is defined as criminal offences committed against tourists and visitors. Still, conducting research of this phenomenon among tourists is not an easy task, as no official statistics distinguish acts committed against tourists from those against the locals. Also, tourists can become both victims and be themselves co-perpetrators of a number of criminal offences (e.g. those against the tourist infrastructure, or the servicing staff) (Tarlow 2011). P.E. Tarlow (2011) also pays attention to the fact that the visitors who have become victims of crime frequently cooperate with their perpetrators intentionally or unintentionally. Furthermore, even if the victim has nothing to do with the crime, there are certain social conditions that render tourists particularly vulnerable to criminal acts.

Undoubtedly, crime in tourism is a phenomenon that may be targeted at various groups. Visitors can also be drawn into illegal activities of criminals, such as e.g. taking drugs or psychoactive substances, taking part in illegal events or incidents including prostitutions, property damage, transportrelated crimes, petty and large-scale theft, and in some cases gross crimes, such as murder. "Tourist" criminals are professionals: they know tourists' behaviour patterns very well, and they know that in most cases their acts will never be reported to the police. Tourists become easy victims or accomplices of prohibited acts, which stems from a number of conditions. One of them is that, once they have left their place of permanent residence, tourists often leave their routine there and travel to places where they are looking for a chance to "get away from it all", and this, in turn, brings their alertness levels down. Criminals are able to spot and identify an average visitor very easily, and if, additionally, he does not know the local culture or customs, chances are that he will become a victim of crime. Also, tourists are often disorganised, which means that they are an easy target for criminals. These are just a few of the determinants at stake. Both tourists and visitors are exposed a wide array of crime-related events and incidents. Yet, it turns out that some of them occur a lot more frequently than others. They include, above all, so-called distraction crimes, i.e. incidents where criminals take advantage of the tourists' overall distraction, their disorganisation resulting from the fact that they have just come to a new place, they are dealing with a new culture, and they need to deal with otherness. Such cases include, above all, pickpocketing, fraud, stolen luggage at airports, stolen documents, or credit cards, but they can also be much more sophisticated and rest on a number of IT procedures that lead to "identity theft" (Tarlow 2011). In his work, Alejziak (1995) also points to the growth of tourism and the more and more worrying increase of crime threats, an increase of dysfunctional incidents, as well as the general deterioration of the levels of public safety and security. He puts emphasis on the fact that given the growth and rising importance of tourism for many towns and cities across Poland, it is necessary to consider whether there is any link between the growth of tourism and a higher crime rate, and dysfunctional incidents. At the same time, the author points to the fact that Poland still lacks studies that would allow to determine whether tourism indeed contributes to the intensification of negative occurrences. One can assume that the inflow of a large group of people such as tourists - hence, an increase in the overall number of people residing in a given area will result in a bigger risk of crime. Having said this, research on this issue is scarce. Although the range of studies on these phenomena analysed on an individual basis is substantial, there is still a clear lack of studies that would combine these two areas that are of key importance from the point of view of safety and security.

\section{CONCLUSIONS AND RECOMMENDATIONS}

This paper has been devoted to a closer analysis of a selection of issues related to the major threats posed for safety and security in tourism. Given the restricted volume of this publication, they have been merely mentioned and succinctly outlined. For sure, the issues at stake have not been developed in an exhaustive manner, which was indeed the author's intention. Based on the paper, one can draw one constructive conclusion: safety and security in tourism is a multidimensional problem that can be and should be looked at on a number of dimensions by experts in different disciplines.

There are several threats that are different in their nature and that bloc shape a general image of a country's level of safety 
and security. A multi-dimensional analysis of the safety and security of a tourist region ought to be carried out by taking into account the context of a plethora of possible criminal acts that may occur there. To get the bigger picture of the area discussed, it is necessary to monitor the occurrences on a regular basis. As regards tourists, specific preventive measures should be taken to show them the types of risk they will be exposed to once they take up various forms of tourism.

The literature-based research that has been conducted for this paper enables to formulate the following conclusions:

I. Tourism is a significant part of Poland's economy, which is why analyses of issues that have an impact on tourism and are generated by it are of key importance, including the negative ones.

II. Data aggregation makes it possible to conduct research at the level of entire urban units and regions; yet, there is a clear shortage of publications concerning smaller areas, like e.g. specific tourist areas in towns and cities.

III. Crime statistics fail to include a clear subdivision into incidents concerning the locals and the visitors and tourists as victims and perpetrators, which implies that there are still only a few reliable publications that include an in-depth analysis of both phenomena, i.e. tourism and crime as two interwoven issues and "two sides of the same coin."

IV. The majority of studies related to crime in tourism are works written in English.

V. The literature on the subject that has been reviewed usually refers to various tourist destinations and related aspects; yet, all the studies aim to formulate only general patterns, which allows one to get a wider perspective of the issues discussed in the paper.

\section{REFERENCES}

Alejziak W. (1995)Turystyka a przestępczość $i$ zjawiska patologii społecznej(zarys problematyki $i$ koncepcja badań na przykladzie Krakowa)."Folia Turistica", vol. 5, pp. 27-97.

Bartoszewicz W., Laciak J.(1989) Dwa punkty widzenia: gospodarcze $i$ turystyki. Turystyka jakoczynnik rozwoju społeczno- -gospodarczego. Wyniki prac z lat 1986-87, Rocznik CPBP, Warszawa: Instytut Turystyki.

Horodecka A. (2008)Ewolucja celów polityki gospodarczej. Rola zmian otoczenia, Warszawa: Wyd. Naukowe PWN.

Idziak P. (2009) Konkurencyjność muzeów w gospodarce doznańi kreatywności. Stasiak (ed.), Kultura i turystyka - wspólnie zyskać!. Łódź: Wyd. WSTH w Łodzi, pp. 219-237.

Jonas H. (1996) Zasada odpowiedzialności. Etyka dla cywilizacji technologicznej. Kraków: Wyd. Platan.

Kowalik T. (2000) Wspótczesne systemy ekonomiczne. Powstanie, ewolucja, kryzys. Warszawa: Wyd. Wyższej Szkoły Przedsiębiorczości i Zarządzania.

Lisowska A. (2017)Zjawisko przestępczości $w$ destynacjach turystycznych przegląd badań, Turyzm, vol. 27/1, pp. 33-43.

Mansfeld Y., Pizam A. (2006) Tourism and Safety Issues, [in:] Tourism. Security and safety, Burlington-Oxford: Elsevier, pp. 139-141.

Piontek B., Piontek F., Piontek W. (1997)Ekorozwój I narzędzia jego realizacji. Białystok:Wyd. Ekonomia I Środowisko.
Pizam A. (1999)A comprehensive approach to classifying Acts of crime and violence at tourism destinations, Journal of Travel Research, vol. 38 (1), pp. 512.

Przecławski K.(1983) Turystyka jako czynnik przemian społeczno-kulturowych środowiska. Problemy Turystyki, vol. $1 / 2$.

Rogalewski O.(1972) Podstawy gospodarki przestrzennej $w$ turystyce. Warszawa: Zakład Graficzny Politechniki Warszawskiej.

Sanetra, B and Sanetra-Półgrabi, S. (2019). Local authorities and tourism: the role of regional tourist products in Poland. Tourism and Travelling, 2(1), 1623. doi:10.21511/tt.2(1).2019.03

Stasiak A. (2015)Turystyka kontrowersyjna jako emanacja gospodarki doświadczeń, [w:] G. Godlewski, M. Zalech (ed.), Turystyka kontrowersyjna na współczesnym rynku podróży - formy, uwarunkowania, skutki, AWF im. Józefa Piłsudskiego w Warszawie, Filia w Białej Podlaskiej, Biała Podlaska,pp. 53-69.

Tarlow P.E. (2011) Crime and Tourism [in:] J. Wilks, D. Pendergast, P. Leggat (eds.), Tourism in turbulent time (Towards Safe Experience for Visitors), pp. 93-101.

Wodejko S. (1998) Ekonomiczne zagadnienia turystyki. Warszawa: Wyższa Szkoła Handlu i Prawa.

http://bazhum.muzhp.pl/media//files/Ekonomiczne_Problemy_Uslug/Ekonom iczne Problemy Uslug-r2012-t-n82/Ekonomiczne Problemy Uslug-r2012-tn82-s357-370/Ekonomiczne_Problemy_Uslug-r2012-t-n82-s357-370.pdf 